\title{
Glacier and runoff changes in the Rukhk catchment, upper Amu-Darya basin until 2050
}

\author{
Wilfried Hagg a,*, Martin Hoelzle ${ }^{\mathrm{b}}$, Stephan Wagner ${ }^{\mathrm{c}}$, Elisabeth Mayr ${ }^{\mathrm{a}}$, Zbynek Klose ${ }^{\mathrm{d}}$ \\ a Department of Geography, Ludwig-Maximilians-University, Luisenstr. 37, 80333 Munich, Germany \\ ${ }^{\mathrm{b}}$ Department of Geosciences, University of Fribourg, Chemin du Musée 4, 1700 Fribourg, Switzerland \\ c ITos-GmbH, Bitzi 2555, 9642 Ebnat-Kappel, Switzerland \\ d Department of Water Resources and Environmental Modeling, Czech University of Life Science, Kamycka 1176, 16521 Prague, Czech Republic
}

\begin{abstract}
A conceptual hydrological model was set up in the upper Panj catchment, the main tributary of Amu-Darya river. After a manual calibration procedure involving model runs with different restrictions, the model reproduced both daily hydrographs of Tanimas river at the Rukhk gauging station (NSE $=0.86$ ) and the snow water equivalent of the Irkht station $\left(\mathrm{R}^{2}=0.85\right)$ in a very satisfactory way. Based on two glacier inventories from the mid-20th century (WGI, World Glacier Inventory) and from 2003 (GLIMS, Global Land Ice Measurements from Space), a simple parameterization scheme based on steady state conditions was applied to infer the ice volumes and glacier areas for these different time periods. Assuming temperature rises of $2.2{ }^{\circ} \mathrm{C}$ and $3.1{ }^{\circ} \mathrm{C}$, which mark the extreme values of regional climate scenarios, the same method was used to extrapolate glacierization to the year 2050. The results show that these temperature rises will reduce the current glacier extent of $431 \mathrm{~km}^{2}$ by $36 \%$ and $45 \%$, respectively.

To assess future changes in water availability, the hydrological model input was modified according to the regional climate scenarios and the resulting glacier changes. The use of an elevation distributed deglacierization pattern is a clear improvement over methods used previously, where the impact on runoff was tested by excluding either the lower half or the total glacier area. The runoff scenarios reveal only a slight reduction in annual runoff, because the glacier area decrease is almost balanced out by enhanced melt rates. However, there is an important seasonal shift of water resources from summer to spring, unfavorably affecting agriculture and irrigation in the lowlands.
\end{abstract}

\section{Introduction}

In many mountain ranges at mid-latitudes, glaciers represent important water reservoirs on several time scales. They are nourished by solid precipitation and release the water again through melting. In climate zones where accumulation and ablation occur at different times of the year, this leads to a seasonal delay of runoff (Jansson et al., 2003). When glacier mass balance is disturbed in one direction over a longer period, the glacier volume changes. In the case of a prolonged phase of mass loss as currently observed on most mountain glaciers, additional water is released and contributes to streamflow. Lambrecht and Mayer (2009) determined the portion of this excess melt in Austrian catchments. From 1969 to 1998, they found annual values of $1.5-9 \%$ of total discharge, depending on the relative glacier cover. In individual months, this fraction reached $20 \%$ in moderately glaciated basins. A prolonged mass loss gradually lowers the amount

\footnotetext{
* Corresponding author. Tel.: +49892180 6657; fax: +4989218016503.

E-mail addresses: hagg@lmu.de (W. Hagg), martin.hoelzle@unifr.ch (M. Hoelzle), swagner@itos-gmbh.com (S. Wagner), klose@fzp.czu.cz (Z. Klose).
}

of excess water until the glaciers disappear completely and runoff is controlled by precipitation and snow-melt alone.

In climates with relatively high precipitation amounts, the contribution of glacier melt to total runoff is high only in heavily glacierized sub-basins. Weber et al. (2010) modeled the present-day fraction of ice melt in the upper Danube catchment and determined a value of $35 \%$ for a high Alpine head watershed (Vent, glacierization: 35\%). As the relative glacier cover decreases downstream, the portion of ice melt also drops sharply and reaches $2 \%$ after the confluence of the Inn river with the Danube at Passau (glacierization: 0.5\%). In summer months the respective values for the two gauges are $50 \%$ and $6-7 \%$ (Weber et al., 2009). The ice melt signal is quickly superimposed by high precipitation sums at the northern margin of the Alps that turn the glacial runoff regime into a nivo-pluvial one.

In reverse, this means that the relative importance of glacier melt is highest in regions where the ablation season is dry and/or where the mountains are surrounded by arid lowlands. A showcase of such conditions can be found in the basin of the Amu-Darya river, the main tributary to the Aral Sea. In a worldwide comparison of the hydrological significance of mountains, Viviroli and Weingartner (2004) classified the Amu-Darya as one of the rivers with the highest share of 
mountain discharge ( $>90 \%$ ), which is defined as the portion of total runoff which is formed in the mountainous part of a catchment. According to Froebrich and Kayumov (2004), about $80 \%$ of the annual runoff of Amu-Darya river is formed by snow- and glacier melt in the Pamir mountains. Kaser et al. (2010) estimated the contribution potential of seasonally delayed glacier meltwater to total runoff in 18 large river systems on all continents and introduced a population impact index to quantify the potential human dependence on glacier melt. They found that in the Aral Sea basin, this value is by far the highest of all catchments investigated. A population of more than 10 million would suffer from water shortages if the glaciers disappeared. Careless consumption and misuse of water resources make the Aral Sea basin a well-known area of substantial water problems (UNESCO, 2009). The growing demand for water and water use conflicts along the transboundary river increase the need for interdisciplinary approaches to sustainable land and water use in the future (e.g. Martius et al., 2009). This extreme climatological and societal situation makes the region especially interesting for water balance studies. Whereas many authors in the past years worked in lower parts of the Amu-Darya basin where the water is mainly used (e.g., Conrad et al., 2007; Bekchanov et al., 2010), there is a lack of investigations in the headwaters. This might be due to logistic obstacles to accessing the glacier region of the Pamir, to political instability and to the sparse data availability, which restricts scientists to very simple methodology.

In remote high-mountain environments, conceptual hydrological models are widely used due to their limited data requirements. They simulate the hydrological cycle by use of calibrated and lumped equations on a catchment scale, without describing small-scale physical processes. In spite of parameter intercorrelation and uncertainty, which can be a problem especially outside the calibration period (Uhlenbrook et al., 1999), they are often the only feasible way to reproduce river hydrographs. A variety of conceptual runoff models were used by many different authors in glacierized catchments (e.g. Hock, 2003; Verbunt et al., 2003; Schaefli et al., 2005; Juen et al., 2007; Konz et al., 2007; Koboltschnig et al., 2008), also in combination with glacier area development based on area-volume scaling (Stahl et al., 2008) or by parameterizations using ice thickness change patterns (Huss et al., 2010). In high elevations, where a comparable big fraction of runoff is formed by snow- and ice-melt, conceptual degree-day models have the advantage that melt can be described much more easily than precipitation. This allows the application of temperature index approaches in data sparse regions. As mentioned before, the Amu-Darya has an extremely high share of melt-water and is therefore predestined for the application of conceptual melt models. Due to the strong hydrological dependence of arid regions on mountain runoff, the highly glacial runoff regime is conserved far downstream of the Amu-Darya. For this reason, the results of this study also provide important information for the lower reaches of the Aral Sea basin.

The hydrological model picked for this study is the HBV-ETH model. It was designed for the application in glacierized catchments and already proved its robustness in various basins in the Alps (Braun et al., 2000), the Himalayas (Braun et al., 1993), the Tian Shan (Hagg et al., 2006, 2007) and the Caucasus (Hagg et al., 2010). In all these studies, the model was calibrated manually in order to understand the hydrological behavior of the catchment and the sensitivity of the parameters. To restrict uncertainty, parameter ranges were narrowed by expert knowledge and a priori assumptions. In this contribution, a calibration exercise employing four calibration modes with different requirements helped to constrain parameter values and to reduce equifinality.

In heavily glacierized regions, runoff is strongly regulated by glacier melt and a prediction of future discharge requires information about future glacier extent. The absence of such information was a weak point in the HBV-ETH applications mentioned above. By assuming three steps of deglacierization $(100 \%, 50 \%, 0 \%)$ without knowing the timing of their occurrence, the runoff scenarios tended to have the character of a sensitivity study. The $50 \%$ deglacierization scenario was realized by excluding the lower half of the glacier area in the topographic input file, which is a simplification that introduces further uncertainties. Despite these restrictions, this simple methodology was adopted by other authors (e.g. Akhtar et al., 2008), probably due to the difficulties involved in a more realistic prediction of future glacier extent.

In order to calculate future discharge, the change in ice volume and glacier extent must be taken into account using parameterizations for glacier retreat (Schaefli et al., 2007; Huss et al., 2010) or coupled models for glacier mass balance and ice-flow dynamics (e.g., Jouvet et al., 2009). Numerical modeling has some restrictions (Le Meur et al., 2004) and the input requirement for fully coupled models increases strongly and processing time is in order of magnitudes higher than for the parameterizations. We use a parameterization scheme based on Haeberli and Hoelzle (1995) to predict elevation-distributed glacierization for the mid-21st century. This glacier model was set up with the help of past and recent glacier inventories (WGMS, 1989; Raup et al., 2007) and digital elevation models (ASTER-GDEM).

The overall aim of this contribution is to estimate future hydrological conditions for the middle of this century, a time horizon important for water resource planning. This requires a classical scenario-led ("top-down") impact assessment, where regional climate scenarios determine the input of hydrological models which subsequently quantify future consequences. An alternative approach would have been "bottom-up", where allowed consequences are defined first and in a second step, the likelihood of future conditions to be within the defined margin is determined with an ensemble of regional climate scenarios (e.g. Prudhomme et al., 2010). Such studies are used to assist vulnerability management and to create adaption strategies (Carter et al., 2007) and are often preferred by policy and decision makers, but they are not suitable to estimate the range of possible reactions or the most probable hydrological responses.

\section{Regional setting}

Amu-Darya is one of the two inflows into the Aral Sea; $68 \%$ of total runoff in the Aral Sea basin is formed in its catchment (UNEP, 2006). While almost $90 \%$ of the total annual discharge of $78 \mathrm{~km}^{3}$ originates from the mountain areas of Tajikistan and Afghanistan (UNEP, 2006), most of the water consumption takes part in the highly arid zones of the downstream riparians (Turkmenistan, Uzbekistan).

From Kerki to Nukus, Amu-Darya loses almost all of its water, mainly by artificial use. According to the Interstate Commission for Water Coordination in Central Asia, up to 4 mill. $\mathrm{km}^{2}$ of land in the basin are irrigated (ICWC, 2010), for the most part still using the outdated and inefficient infrastructure from the Soviet period. Another major source of water loss is the Karakum canal which diverts $8-12 \mathrm{~km}^{3}$ per year from the Aral Sea Basin to Turkmenistan (Glantz, 2005). As a response, Aral Sea has lost 90\% of its volume from 1960 to 2006 (Micklin, 2007).

Amu-Darya is formed at the confluence of the rivers Vakhsh and Panj, the latter contributing $986 \mathrm{~m}^{3} / \mathrm{s}$ or $60 \%$ to total annual runoff. According to the World Glacier Inventory (WGMS, 1989) prepared in the mid-20th century, the Panj catchment has a glacier coverage of $3913 \mathrm{~km}^{2}$, corresponding to a glacierization of $3.4 \%$. A comparison of data from the GLIMS project (Zheltyhina, 2005) with the World Glacier Inventory (WGI) revealed that from the mid 20st century until 2003, glacier area in the whole Panj basin decreased by $8.2 \%$ only (Hoelzle et al., 2010), equaling a mean rate of less than $2 \%$ per decade.

Rukhk is a village and hydrological post at the Tanimas river, which becomes the river Bartang at the confluence with the Murghab river (Fig. 1). The Rukhk catchment, which is investigated in this study is $4306 \mathrm{~km}^{2}$ in size, it stretches from 2650 to $6940 \mathrm{~m}$ asl and has a glacier 
cover of $431 \mathrm{~km}^{2}(10 \%)$. In contrast to the adjacent Fedchenko glacier, which is completely debris-mantled on its lower parts, most glaciers in the Rukhk catchment are debris-free or have only marginal debris covers. Some glaciers on the orographic right side of Tanimas river have more heavily debris covered tongues, but they are small in number and size. Five years of daily discharge measurements (1985/86-1989/90, Tajik Met Service) are available at the Rukhk gauge. The hydrographs show a distinct glacial regime with maximum values in July and August. Meteorological data were taken from the Irkht station (3290 m asl) close to Lake Sarez (Fig. 1). This station is located outside the Rukhk catchment, but the close proximity (approx. $23 \mathrm{~km}$ from Rukhk) suggests that the data are still representative for the meteorological conditions inside the test basin. Irkht offers a valuable long-term series (since 1939) from this strongly continental mountain region. Mean monthly temperatures (1939-1994) range from $-13.6{ }^{\circ} \mathrm{C}$ in January to $14.4{ }^{\circ} \mathrm{C}$ in July, the resulting inter-annual amplitude is $28 \mathrm{~K}$. Precipitation is very low due to the leeward location with respect to the Central Pamir (Schiemann et al., 2008). Mean annual sums in the five years of discharge observations are only $139 \mathrm{~mm}, 72 \%$ of which occur from December to May, mostly in solid form. Only $12 \mathrm{~mm}$ or $8.6 \%$ fall in July to August, when $46 \%$ of annual runoff is formed and when the demand for irrigation water is highest. These numbers impressively demonstrate the importance of ice melt for runoff formation and seasonal redistribution.

The dominance of melt processes is a benefit for hydrological modeling, because they can be simulated satisfactorily even in data sparse regions. The relatively low horizontal variability and the well-known vertical lapse rates of air temperature make it feasible to extrapolate this parameter, also from a single meteorological station. Air temperature is a good index for melt, because it is correlated with all terms of the energy balance except for latent fluxes, which can disturb this relation in both directions (Ohmura, 2001). For this reason, melt rates in continental climates, where evaporation dominates throughout the year, are even stronger correlated to air temperature than in maritime settings, where both condensation and evaporation occur. This justifies the application of simple degree day models in highly continental regions such as the Amu-Darya basin. The dry climate on the lee side of the highest ranges further limits spatial differences in precipitation. The moisture content of the air is very low and even big relative differences in precipitation sums mean only small absolute differences compared to a more humid climate. This gives further confidence in simulating a relatively large catchment such as the Rukhk catchment with data from a single meteorological station.

Agaltseva et al. (2005) conducted regional climate modeling to assess future climate change in the mountainous part of the upper Amu-Darya basin. In order to partly moderate uncertainties of climate models, the averaged results of six General Circulation Models (HadCM3, ECHAM4, CSIRO-TR, GFDL-TR, CGCM1-TR, CCSR-NIES) were used (source: WCRP CMIP3 multi-model dataset, Meehl et al., 2007b). Five emission scenarios (A1B, A1FI, B1, A2, B2, see Nakicenovic et al., 2000) formed the basis for characterizing climate changes by three time intervals in the future $(2030,2050$ and 2080) with respect to the baseline scenario 1961-1990. Statistical downscaling was performed by multivariate linear regression and is based on observational data from 22 stations in the case of air temperature, and 21 stations in the case of precipitation (Agaltseva et al., 2005). For mid-century, the mean warming in the mountain region ranges from $2.2{ }^{\circ} \mathrm{C}$ ("moderate scenario") to $3.1{ }^{\circ} \mathrm{C}$ ("hot scenario") and is evenly distributed over the year. To cover the full range of possible reactions, we selected these two extreme scenarios to estimate changes in glacierization and runoff. The corresponding precipitation changes for Fedchenko station (4156 $\mathrm{m}$ asl) are given in Table 1. Expected annual changes are low increases, ranging between 3 and $4 \%$. Seasonal values reveal slight increases in all cases except for spring in the hot scenario $(-3.7 \%)$, winter snow accumulation will be augmented by $3.0 \%$ (moderate scenario) and $8.5 \%$ (hot scenario).

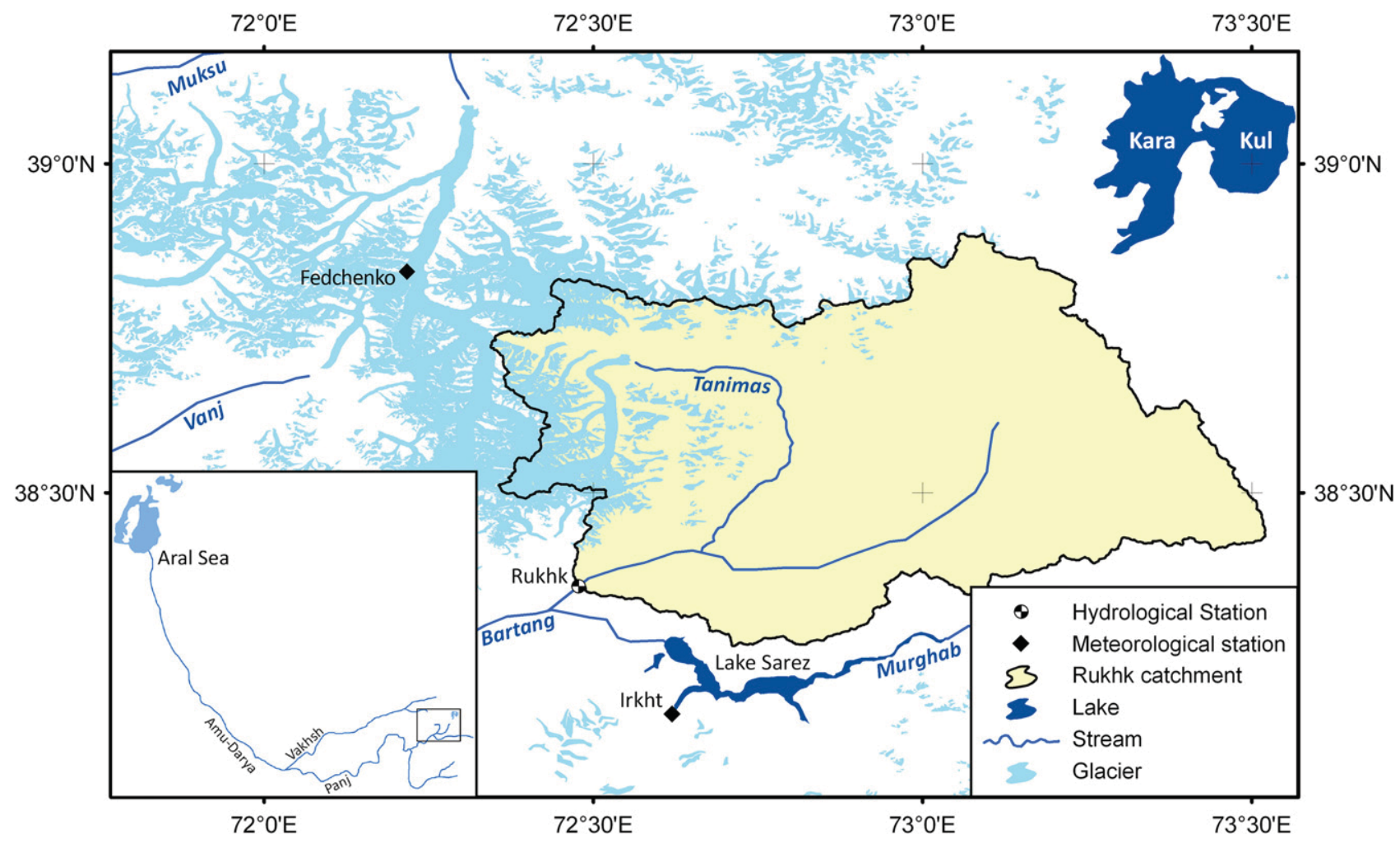

Fig. 1. Sketch map of the Rukhk catchment. 


\section{Materials and methods}

\subsection{Processing of input data}

The glacier parameterization uses World Glacier Inventory data of the investigation area from two time frames. The older data (1940s to 1960s) were derived mainly from aerial photographs, while the outlines (polygons) from the younger period (20002003) had to be updated from the GLIMS database (Zheltyhina, 2005). Nearly all existing glacier polygons had to be corrected for their position and updated using self-digitized polygons, which were manually derived from LANDSAT satellite images from 2003, representing the same basis as in the GLIMS-database. The parameterization scheme was applied to some representative glaciers in both inventories and the results were extrapolated to the whole investigation area to provide an estimation of the total ice volume and the ice volume change for the period 2003 to 2050.

Topographic input for the hydrological model consists of a distribution of area by altitude and orientation classes, separately for glaciated and non-glaciated areas. For the Rukhk catchment, this data were calculated from digital elevation models (ASTER-GDEM version1) an elevation model with $30 \mathrm{~m}$ ground resolution and a product of METI and NASA (http://www.gdem.aster.ersdac.or.jp/). The catchment was divided into $300 \mathrm{~m}$ elevation bands and into three orientation classes (South, North and East-West-horizontal) (Fig. 2). Terrain with slopes smaller than $5^{\circ}$ was classified as horizontal. The ASTER images used to generate the elevation models were taken in the 2000-2006 period, some 10-20 years after the available hydrometeorological data. Since no maps or elevation models from the 1980s are available and due to the lack of better options, this inaccuracy was accepted.

\subsection{Glacier parameterization}

The parameterization scheme developed by Haeberli and Hoelzle (1995) provides the possibility to analyze glacier inventory data stored in the databases of the World Glacier Monitoring service (WGMS) and the National Snow and Ice Data Center (NSIDC). These past inventories are mainly based on aerial photography, in contrast to the newer inventories, which rely on satellite images Paul (2010). Detailed information about the complete parameterization scheme can be found in Haeberli and Hoelzle (1995), Hoelzle and Haeberli (1995), Hoelzle et al. (2003, 2007) and Baumann and Winkler (2010). Here, a brief summary of the most important steps is provided. Only five measured input variables from the inventories were used, namely maximum glacier altitude $\left(\mathrm{H}_{\max }\right)$, mean altitude $\left(\mathrm{H}_{\text {mean }}\right)$, minimum altitude $\left(\mathrm{H}_{\min }\right)$, length $\left(\mathrm{L}_{0}\right)$ and total surface area $(\mathrm{F})$. All other variables are calculated or taken from measurements. Where specific equations are not given, the corresponding references are cited.

This approach considers step changes after full dynamic response and new equilibrium of the glacier have been achieved, when mass balance disturbance $\Delta \mathrm{b}$ leads to a corresponding glacier length change $\Delta \mathrm{L}$ that depends on the original length $\mathrm{L}_{\mathrm{o}}$ and the average annual mass balance (ablation) at the glacier terminus $b_{t}$. Therefore, this approach does not consider any transient changes. The term $b_{t}$ is

\section{Table 1}

Expected seasonal precipitation shift (\% rate of base norm calculated for 1961-1990) in 2050 according to the climate scenarios with the lowest and highest temperature increase (after Agaltseva et al., 2005).

\begin{tabular}{llclll}
\hline & Winter & Spring & Summer & Autumn & Year \\
\hline Moderate scenario $\left(+2.2^{\circ} \mathrm{C}\right)$ & 3.0 & 0.2 & 4.7 & 7.7 & 3.1 \\
Hot scenario $\left(+3.1^{\circ} \mathrm{C}\right)$ & 8.5 & -3.7 & 6.6 & 9.2 & 3.9 \\
\hline
\end{tabular}

calculated as $b_{t}=d b / d h\left(H_{\text {mean }}-H_{\text {min }}\right)$, where $\mathrm{db} / \mathrm{dh}$ is the mass balance gradient:

$\Delta \mathrm{b}=\mathrm{b}_{t} \cdot \Delta \mathrm{L} / \mathrm{L}_{0}$

Glacier thickness (h) is determined according to Eq. (2) (Paterson, 1994) where $\alpha$ is the slope, $\tau$ the basal shear stress, $\rho$ the density of ice and $g$ the acceleration due to gravity.

$\mathrm{h}=\tau / \rho \cdot \mathrm{g} \cdot \sin \alpha$.

The dynamic response time $t_{\text {resp }}$ is calculated after Jòhannesson et al. (1989), where $\mathrm{h}_{\max }$ is a characteristic ice thickness, usually taken at the equilibrium line where ice depths are near maximum. $\mathrm{h}_{\max }$ is calculated as $2.5 \mathrm{~h}$, as estimated from known ice thickness measurements on various Alpine glaciers worldwide (March, 2000; Bauder et al., 2003; Farinotti et al., 2009).

$\mathrm{t}_{\text {resp }}=\mathrm{h}_{\max } / \mathrm{b}_{t}$.

Assuming a linear change of the mass balance from $b$ to zero during the dynamic response, the average mass balance $<\mathrm{b}\rangle$ can be calculated according to Eq. (4). $<\mathrm{b}>$ values are annual ice thickness change (meters of water equivalent (we) per year) averaged over the entire glacier surface, which can be directly compared with values measured in the field. Although the method is quite simple, the results compare very well with long-term observations (Hoelzle et al., 2003). The factor $\mathrm{n}_{\text {resp }}$ denotes the count of possible response times for each glacier within the considered time period.

$<\mathrm{b}>=\Delta \mathrm{b} / 2 \cdot \mathrm{n}_{\text {resp }}$.

Due to his representative location and typical topographic features, Abramov glacier was considered a reference glacier for the PamirAlay during the Soviet era and also serves as such in this study. Although it lies $115 \mathrm{~km}$ outside the basin under investigation, it is the nearest glacier for which the required data are available. A mass balance gradient of $9.0 \mathrm{~mm} \mathrm{~m}^{-1}$, derived from measured data at Abramov (Pertziger, 1996), was chosen for the entire sample. The value is in good agreement with the mass balance gradient of $8.8 \mathrm{~mm}$ derived by the HBV-ETH model. However, we decided to use the measured value as input for the glacier parameterization in order to keep the methods independent from each other. The parameterization was applied to 82 selected glaciers, where glacier information from both inventories could be compiled. The resulting differences of the modeled volumes were then extrapolated to an overall volume change for the whole test basin.

Mean specific mass balances were estimated using a relation found by Kuhn (1990), which states that a temperature change of $+1{ }^{\circ} \mathrm{C}$ increases the equilibrium line altitude (ELA) by $170 \mathrm{~m}$ with an accuracy of $\pm 50 \mathrm{~m}$ per degree Celsius. The corresponding change in mass $(\Delta \mathrm{b})$ was calculated using the mass balance gradient $(\mathrm{db} / \mathrm{dh})$ after Eq. (5).

$\Delta \mathrm{b}=\mathrm{db} / \mathrm{dh} \cdot \mathrm{dELA} / \mathrm{dT}_{\text {air }} \cdot \Delta \mathrm{T}_{\text {air }}$

where $\mathrm{dELA} / \mathrm{dT}_{\text {air }}$ describes the vertical shift of ELA per degree Celsius and integrates the change in all climate parameters, i.e. radiation, humidity, accumulation and air temperature, as well as feedback effects for any temperate glaciers (Kuhn, 1993).

The calculation of the $<\mathrm{b}>$ value was done by taking into account each individual response time and multiples thereof (Eq. (4)). According to Eq. (5) an increase in temperature of 2.2 and $3.1^{\circ} \mathrm{C}$ with a corresponding ELA shift of $374 \mathrm{~m}$ and $527 \mathrm{~m}$ would lead to a $\Delta \mathrm{b}$ of $3.37 \mathrm{~m}$ and $4.74 \mathrm{~m}$, respectively. 


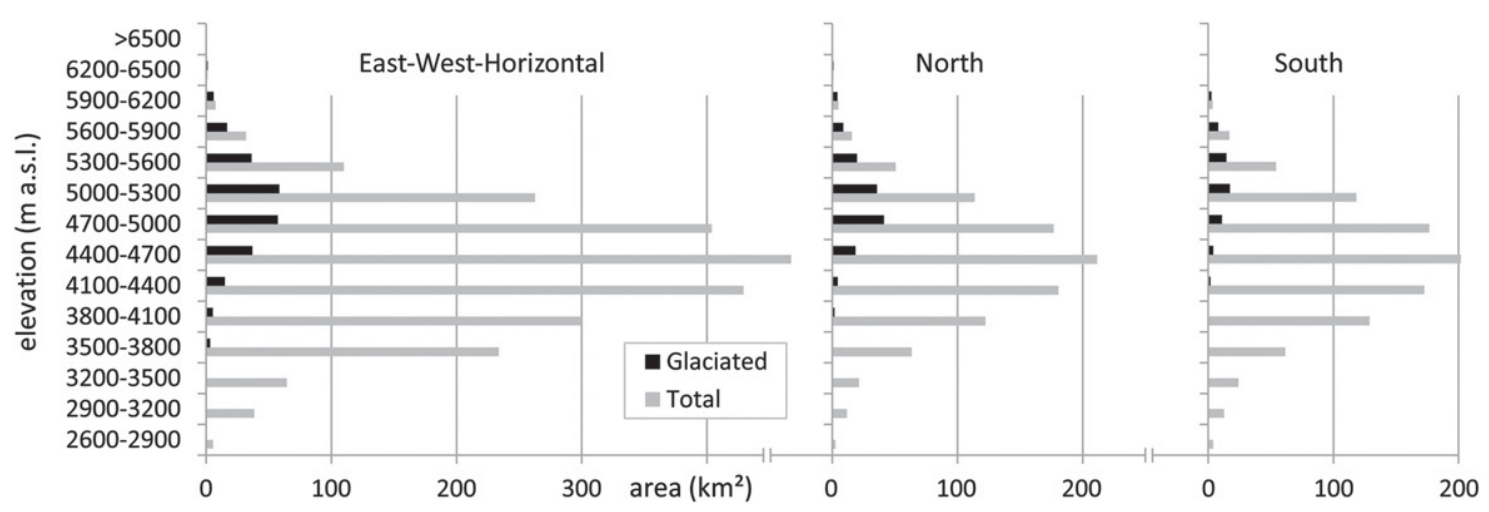

Fig. 2. Distribution of area by altitude and orientation classes for the total area and the glaciated part of the Rukhk catchment.

The output of the used parameterization, mainly the calculated glacier area in 2050 after full adjustment to the new climate setting as presented above, serves as input for the HBV-ETH model.

\subsection{Hydrological model}

The HBV-ETH model (Braun and Renner, 1992) is a further development of the worldwide used HBV model (Bergström, 1976). Required input consists of topographical data (distribution of area and orientation classes by altitude, separately for glaciated and total area) and hydrometeorological data (daily values of air temperature and precipitation to drive the model, and runoff for calibration).

The first of three model components is the snow and glacier routine. Here, a threshold air temperature (T0) distinguishes solid precipitation from rainfall and both aggregational states of precipitation are corrected by factors (SCF, RCF) to account for gauge undercatch errors and for the representativeness of the weather station for the catchment. Precipitation is assumed to increase with elevation by a linear the lapse rate (PGRAD). Melting of snow and ice is calculated with a temperature index approach using a seasonally variable degree day factor, forming a sinus curve with a maximum (CMAX) and a minimum (CMIN) value at the summer and winter solstices, respectively. The degree day factor (DDF) for each day is calculated by Eq. (6)

$\operatorname{DDF}(\mathrm{i})=(\mathrm{CMAX}-\mathrm{CMIN}) / 2 \cdot \cos (2 \Pi / \mathrm{maxDay} \cdot \mathrm{i})+\mathrm{CMIN}$

$+(\mathrm{CMAX}-\mathrm{CMIN}) / 2$

where $\mathrm{i}$ is the day, numbered from 0 (on 21st June) until maxDay and maxDay is the number of days in a year minus 1 .

Snow-melt (M) on plain terrain is estimated by the degree day approach shown by Eq. (7)

$\mathrm{M}=\mathrm{DDF}(\mathrm{i}) \cdot(\mathrm{TM}-\mathrm{T} 0)$

and occurs only if daily mean temperature (TM) is above the threshold temperature (T0).

Differences in incoming solar radiation due to topography are considered by the factor REXP $(>1)$. On south-facing slopes, melt is multiplied by REXP, while on north-facing slopes it is divided by the same value. To account for the lower albedo of ice compared to snow, melt on glaciated areas is multiplied by the factor RMULT $(>1)$ as soon as an elevation band becomes snow-free.

Surface melt and liquid precipitation can infiltrate into the snow pack and build up a liquid storage (SLIQ). The maximum storage of liquid water in the snow pack (SLIQMAX) depends on the snow water equivalent (SP) and the water-holding capacity (CWH) as shown by Eq. (9).
Below the threshold temperature T0, the liquid storage (SLIQ) is refreezing (CMELT) according to Eq. (8):

CMELT $=(\mathrm{TM}-\mathrm{T0}) \cdot 4.5 \cdot \mathrm{CRFR}$

and CRFR the coefficient of refreezing. The value 4.5 is the mean degree day factor for alpine settings (Zingg, 1951). CMELT is always negative and reduces the liquid water storage within the snow pack (SLIQ).

While precipitation and melt in the snow and glacier routine are treated semi-distributed for different elevation bands and orientation classes, the following steps of the model are performed on a lumped basis for the whole catchment area. In our relatively large study area, this seems to be justified by the uniform landscape pattern due to the absence of vegetation.

The second model component is the soil routine. It receives the sum of melt-water and precipitation (RS) from the snow and glacier routine and computes actual evapotranspiration (EA) as a function of potential evaporation (EP) and the fill level of the soil moisture reservoir (SSM) after Eq. (10).

$\mathrm{EA}=\mathrm{EP} \cdot(\mathrm{SSM} / \mathrm{LP})$

LP is the particular fill level of the reservoir, below which EA is assumed to equal EP.

Potential evapotranspiration (EP) varies sinusoidally throughout the year with a minimum of zero on 30th January and a maximum (ETMAX) on 1st August according to Eq. (11)

$\mathrm{EP}=0.5 \cdot \operatorname{ETMAX} \cdot[1+\sin (\mathrm{j} \cdot 2 \mathrm{n} / \operatorname{maxDay})]$

where $\mathrm{j}$ is the day, numbered from 0 (on 2 May) until maxDay.

The third model component is the response function, where the remaining water is transformed into a flow hydrograph. The inflow to the response function (DSUZ) is calculated by the inflow into the soil routine (RS), its fill level (SSM), the field capacity (FC) and a coefficient (BETA) according to Eq. (12).

$\mathrm{DSUZ}=\mathrm{RS} \cdot(\mathrm{SSM} / \mathrm{FC})^{\text {BETA }}$.

The response function has an upper and a lower storage and three outflows with different response times controlled by constants $\left(\mathrm{k}_{0}, \mathrm{k}_{1}, \mathrm{k}_{2}\right)$. Quick runoff $\left(\mathrm{Q}_{0}\right)$ from the upper storage is determined by Eq. (13).

$\mathrm{Q}_{0}=\mathrm{k}_{0} \cdot(\mathrm{SUZ}-\mathrm{LUZ})$

and only appears if the fill level of the upper storage (SUZ) exceeds a certain threshold (LUZ). Intermediate outflow $\left(Q_{1}\right)$ is also released from the upper storage and is calculated accordingly ( $\mathrm{k}_{1} \mathrm{SUZ}$ ). Percolation from the upper to the lower (ground water) storage is controlled by the 
constant CPERC and from the lower storage, slow runoff $\left(\mathrm{Q}_{2}\right)$ is formed as the product of $\mathrm{k}_{2}$ and the fill level of the lower storage (SLZ).

The three outflows are summed up and form total runoff.

\subsection{Calibration of the hydrological model}

The HBV-ETH model was calibrated manually using the model efficiency (NSE) after Nash and Sutcliffe (1970) and the percent bias (PBIAS) in runoff volume (Gupta et al., 1999) as objective functions. The ratio of the root mean square error to the standard deviation of measured data (RSR) was further used to assess model performance as proposed by Moriasi et al. (2007). The lower the root mean square error and RSR, the better the model performance. A perfect fit between modeled and observed hydrographs would yield a NSE of 1.0 and PBIAS and RSR of $0 \%$ and 0.0 , respectively. The equations used were:

$\mathrm{NSE}=1-\frac{\sum_{i=1}^{n}\left(\mathrm{Q}_{m}-\mathrm{Q}_{s}\right)^{2}}{\sum_{i=1}^{n}\left(\mathrm{Q}_{m}-\overline{\mathrm{Q}_{m}}\right)^{2}}$

PBIAS $=\frac{\sum_{i=1}^{n}\left(\mathrm{Q}_{m}-\mathrm{Q}_{s}\right) * 100}{\sum_{i=1}^{n}\left(\mathrm{Q}_{m}\right)}$

$\mathrm{RSR}=\frac{\sqrt{\sum_{i=1}^{n}\left(\mathrm{Q}_{m}-\mathrm{Q}_{s}\right)^{2}}}{\sqrt{\sum_{i=1}^{n}\left(\mathrm{Q}_{m}-\overline{\mathrm{Q}_{m}}\right)^{2}}}$

where $Q_{m}$ is the observed discharge, $Q_{s}$ the simulated discharge, $n$ the total number of calculated time steps and y the total number of years.

Since both basin precipitation and glacier melt are difficult to simulate correctly, verification with measured mass balance data helps to avoid error compensation (Hagg et al., 2004; Schaefli and Huss, 2010; Mayr et al., 2013).

To check the plausibility of the calculated basin precipitation, we compared it with assimilated and gridded precipitation data sets. Reanalysis data are an important source of precipitation estimates in areas with few observations and have also been used in Central Asia before (e.g. Schär et al., 2004; Schiemann et al., 2008). A gridded $\left(0.25^{\circ}\right)$ precipitation dataset for Asia was constructed from interpolated observations within the APHRODITE project (Asian Precipitation - Highly-Resolved Observational Data Integration Towards Evaluation of the Water Resources). We used outputs from the ERA40 reanalysis (Uppala et al., 2005), the REMO regional climate model (Mannig et al., 2013-this issue) and APHRODITE precipitation products (Takashima et al., 2009) to check the basin precipitation resulting from our parameter settings (see calibration mode 2 below).

Direct mass balance observations are not available in the investigation area, but mass losses comparable to those in more maritime mountains were confirmed by repeat photographs in the Tanimas valley (Braun and Hagg, 2009) and by a GPS survey on Fedchenko glacier in 2009 (Lambrecht et al., 2010). As a consequence, the only frame we had to constrain parameters in terms of ice melt was to avoid strongly negative mass changes, balanced conditions, or a gain in glacier mass. To check if the model is able to reasonably describe accumulation and depletion of snow, we used daily snow height observations from the meteorological station Irkht. The snow heights were transformed into snow water equivalents using snow densities computed as a function of mean snow age, following the formulation of Douville et al. (1995). The numerical criterion for the simulation of the snow cover is the squared correlation coefficient $\left(R^{2}\right)$ between modeled snow water equivalents and snow water equivalents derived from observations.

In the HBV-ETH model, calibration of the free parameters is conducted in optimization runs, where two parameters are tested against each other simultaneously. For each parameter, a start value and an increment must be defined. Ten values of each parameter are tested in every optimization run. The results are two matrixes for NSE and PBIAS, each showing 100 values corresponding to each parameter value combination. A color code for the goodness of fit quickly visualizes if the optimum is within the parameter ranges or not. Subsequently, the modeler can narrow the value ranges by choosing smaller increments and a finer resolution of the values, maybe resulting in higher NSE or lower PBIAS values. This step can be repeated until the best value combination is found. Since highest NSE values are typically not reached with the same parameters as the lowest volume error, the modeler has to find a compromise here. This introduces a certain subjectivity, but also lets the modeler decide if his priority is more the shape of the hydrograph or the runoff volume, a question which can depend on the goal of the study. It is important to note that after each optimization, hydrographs are also interpreted visually. This enhances the understanding of the parameter values and their changes. The storage parameters $\left(\mathrm{k}_{0}, \mathrm{k}_{1}, \mathrm{k}_{2}\right)$, for example, can be tuned very effectively by an optical assessment of the declining branches of the hydrograph.

In a next step, the optimization is performed with the next pair of parameters. The most sensitive parameters (RCF, SCF, T0, PGRAD, TGRAD, CMAX) are calibrated first. In this context, it is useful to choose two parameters which are related to different processes (e.g. one controlling precipitation, the other controlling melt) to see if there is more than one optimum, meaning that the model is equifinal. In this case, parameter ranges need to be constrained by the help of other criteria (e.g. glacier mass balance, snow observations, assimilated precipitation data). After all free parameters are calibrated, the whole procedure is repeated with other combinations of parameter pairs. If the calibration is robust, the parameter values and also the numerical criteria (NSE and PBIAS) change only very slightly during this second round.

To ensure independent calibration and validation, the measured time-series is usually divided into two sets (Klemeš, 1986). We divided the period of runoff observations into the two cooler (1988/89 and 1989/90) and the three warmer (1985/86-1987/88) years and used them in turn for calibration and validation, only judging the ability of the model to reproduce runoff. The results of this split-sample test are shown in Table 2. When compared to calibrating over the full series, splitting the 5 years leads to a slightly better performance in the calibration period and a slightly lower performance in the validation period. To avoid biases by the specific meteorological conditions in short periods,

Table 2

Numerical criteria for the model performance using different periods for calibration and validation. Parameters were tuned in order to reach maximum Nash-Sutcliffe efficiencies (NSE) together with tolerable $(<10 \%)$ relative volume errors (PBIAS). The ratio of the root mean square error to the standard deviation of measured data (RSR) was determined after calibration as additional quality check.

\begin{tabular}{|c|c|c|c|c|c|}
\hline \multirow[t]{2}{*}{ Criterion } & \multicolumn{2}{|l|}{ Split sample 1} & \multicolumn{2}{|l|}{ Split sample 2} & \multirow{2}{*}{$\begin{array}{l}\text { Full series } \\
\text { Calibration } \\
\text { 1985/86-1989/90 }\end{array}$} \\
\hline & Calibration 1985/86-1987/88 & Validation 1988/89-1989/90 & Calibration 1988/89-1989/90 & Validation $1985 / 86-1987 / 88$ & \\
\hline NSE & 0.94 & 0.87 & 0.92 & 0.86 & 0.91 \\
\hline PBIAS (\%) & 3.1 & 7.0 & -4.6 & -12.3 & 5.1 \\
\hline RSR & 0.26 & 0.36 & 0.29 & 0.37 & 0.28 \\
\hline
\end{tabular}


we decided to use the complete time-series for further calibration purposes.

To spin up the model, we looped it through the hydrological year $1987 / 88$ for 10 consecutive iterations before we started the model runs that were analyzed for calibration. The model soon reached a dynamic equilibrium, after two iterations the changes were already marginal.

\subsection{Simulation of future runoff}

Runoff scenarios were generated by modifying the meteorological model input by a constant temperature shift throughout the year, according to the evenly distributed warming rates found by Agaltseva et al. (2005). Precipitation was adjusted seasonally according to Table 1

Glacier changes (Fig. 3) were considered in the area-altitude distribution and are based on the glacier parameterization scheme presented in Section 3.2.

\section{Results}

\subsection{Deglacierization}

According to the glacier parameterization, temperature rises of $2.2{ }^{\circ} \mathrm{C}$ and $3.1{ }^{\circ} \mathrm{C}$ until 2050 reduce the current glacier extent by $36 \%$ and $45 \%$, respectively. The deglacierization in the elevation classes of the HBV-ETH model is depicted in Fig. 3.

In the two lowest intervals below $4400 \mathrm{~m}$ asl, glaciers practically disappear. In the following three intervals up to $5000 \mathrm{~m}$ asl, glacier area is reduced by more than $50 \%$, from 5000 to $5300 \mathrm{~m}$ asl by $28-36 \%$ and above $5300 \mathrm{~m}$ asl there are only very minor changes. Regarding the current distribution, the largest absolute losses $\left(56-74 \mathrm{~km}^{2}\right)$ will occur between 4700 and $5000 \mathrm{~m}$ asl.

The availability of areal changes by altitude is a real improvement over former studies, where deglacierization was simulated by "cutting" the lowest glacier parts. In order to determine the differences between these two approaches, additional model runs have been performed with the old deglacierization procedure ("cutting lowest"), where glacier area remains unchanged above $5000 \mathrm{~m}$ asl. and is completely deleted below $4700 \mathrm{~m}$ asl. In the elevation band $4700-5000 \mathrm{~m}$ asl., glacier cover is reduced to $39 \mathrm{~km}^{2}\left(+2.2{ }^{\circ} \mathrm{C}\right)$ and $4 \mathrm{~km}^{2}\left(+3.1^{\circ} \mathrm{C}\right)$.

The parameterization scheme used to derive future glacierization does not allow us to differentiate between the orientation classes used in the hydrological model. It was assumed that relative deglacierization is similar for all orientations.

\subsection{Runoff simulations in the period with observations}

We conducted four calibration modes (1-4), the model performance and the values of the water balance terms are compiled in Table 3. When the model is tuned by runoff only (1), the highest NSE that could be reached was 0.91 . In this calibration mode, any parameter value within very broad ranges was accepted. For example, the best rain correction factor (RCF) found was 0.22 , meaning that if precipitation is assumed liquid, only $22 \%$ of the measured value was taken into account. Solid precipitation was multiplied by 1.2 (SCF). Such parameter values cannot be explained by physical processes, but they can result if the calibration is conducted freely from any restrictions. Using this parameter set, glacier mass balance is unrealistically high. If the basin value of $-192 \mathrm{~mm}$ is related to the glacier area, mean net balances of almost $-2 \mathrm{~m} / \mathrm{a}$ result. Furthermore, the snow cover at Irkht cannot be reproduced, indicating that meteorological variables are not extrapolated correctly.

In a second calibration mode (2), parameter values were restricted to narrower ranges which are more realistic according to our modeling experience in Central Asia. In the case of precipitation correction factors, for example, this means that values should be above 1 unless it seems plausible that the meteorological station receives more precipitation than the basin average due to an especially high and/or wind exposed location. Furthermore, the basin precipitation should be closer to the values derived from APHRODITE $(290 \mathrm{~mm})$, ERA40 $(360 \mathrm{~mm})$ and REMO $(439 \mathrm{~mm})$. These values vary considerably, but indicate that a reasonable basin value should at least be in the order of $300 \mathrm{~mm}$. Other demands for calibration mode (2) were less negative glacier balances and a better simulation of the recorded snow cover at Irkht. By reducing ice and snow melt, the glacier mass balance could be reduced to $-105 \mathrm{~mm}$ and the snow properties can be simulated well. This is illustrated by the correlation between monthly snow water equivalents (Fig. 4b) and by the proper reproduction of the daily course (Fig. 4a). In all years, the timing of snowfalls, the onset of melt and the duration of the snow cover is reproduced very well. HBV-ETH tends to slightly overestimate snow water equivalents, because the model can neither account for snow deflation by wind nor for sublimation losses. Therefore, the snow water equivalent cannot be reduced during periods with air temperatures below zero. As expected, these additional calibration criteria reduce the ability of the model to mimic runoff: the best compromise found has a mean Nash-Sutcliffe value of 0.86 . The reduced glacier melt is mainly balanced by increased precipitation.

In order to test the ability of the model system to compensate for errors in basin precipitation, an additional calibration run (3) was

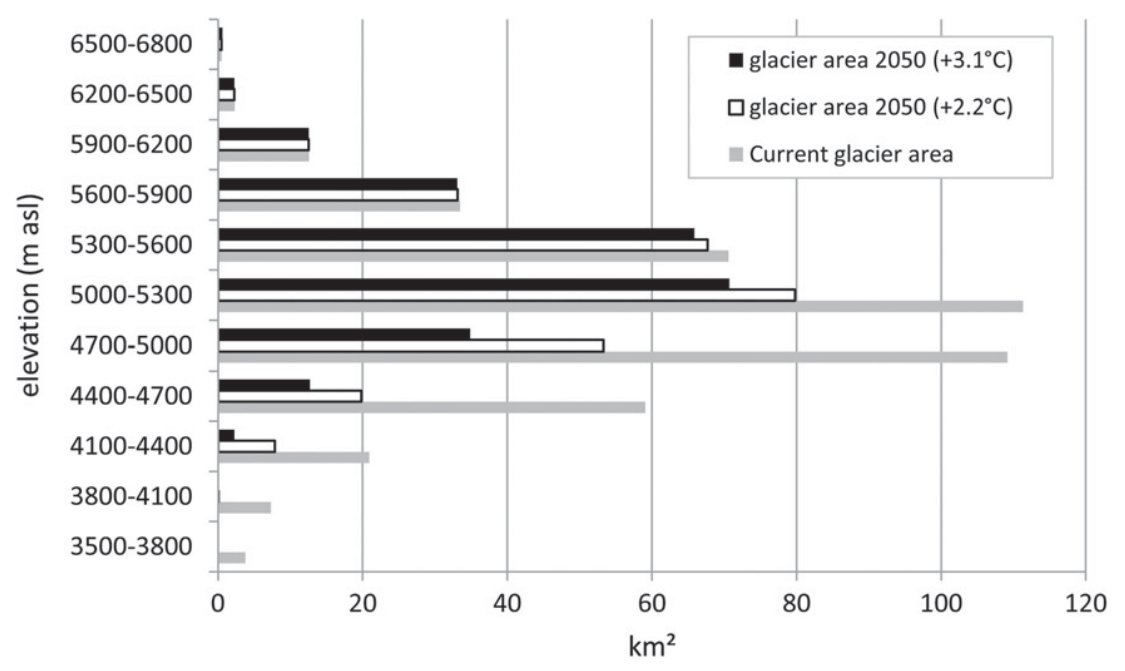

Fig. 3. Current distribution of glacier area by elevation classes in the Rukhk catchment and projections for the year 2050 . 
Table 3

Model efficiency (NSE) after Nash and Sutcliffe (1970), relative volume error (PBIAS), ratio of the root mean square error to the standard deviation of measured data (RSR) and squared correlation coefficient $\left(S^{2}\right)$ between modeled snow water equivalents and snow water equivalents derived from snow height measurements at Irkht (3290 $\mathrm{m}$ a.s.l.). Four different modes of calibration (see text for detailed explanation) and the mean terms of the water balance $(P=$ basin precipitation, $\mathrm{ET}=$ evapotranspiration, GMB = glacier mass balance) are shown in $\mathrm{mm} \mathrm{a}^{-1}$.

\begin{tabular}{llllllll}
\hline Calibration mode & $\begin{array}{l}\text { P } \\
(\mathrm{mm})\end{array}$ & $\begin{array}{l}\text { ET } \\
(\mathrm{mm})\end{array}$ & $\begin{array}{l}\text { GMB } \\
(\mathrm{mm})\end{array}$ & $\begin{array}{l}\text { NSE } \\
(-)\end{array}$ & $\begin{array}{l}\text { PBIAS } \\
(\%)\end{array}$ & $\begin{array}{l}\text { RSR } \\
(-)\end{array}$ & $\begin{array}{l}\mathrm{S}^{2} \\
(-)\end{array}$ \\
\hline (1) Runoff only & 238 & 211 & -192 & 0.91 & 5.1 & 0.28 & 0.52 \\
(2) Runoff + snow cover & 295 & 185 & -112 & 0.86 & 8.5 & 0.38 & 0.85 \\
(3) Double precip. & 590 & 345 & 26 & 0.81 & 17.5 & 0.41 & 0.63 \\
(4) Double precip., neg. & 590 & 480 & -110 & 0.69 & 33 & 0.57 & 0.65 \\
& & & & & & & \\
\end{tabular}

performed. The target was to double basin precipitation, which was realized by increasing the values of RCF, SCF and PGRAD (to 1.5, 1.5 and $15.5 \%$, respectively). The other parameters were tuned again and the results proved that still relatively high model efficiencies of 0.80 can be achieved. However, glacier mass balance becomes positive, which is highly unrealistic. Additionally, evapotranspiration is increased by almost $90 \%$ compared to the previous mode.

In a last calibration run (4), the glacier mass balance is forced to reach realistic values similar to those in (2), while the doubled basin precipitation is kept constant. This resulted in a clear divergence of the hydrographs, the goodness of fit dropped to the mean NSE of 0.65 and PBIAS was highest with $33 \%$. Even more water than in mode (3) needs to be evaporated, yielding mean basin values that exceed runoff by a factor of more than two.

All further model applications were conducted with the parameter values of calibration mode (2), they are listed in Table 4 and the hydrographs are displayed in Fig. 5.

Since daily variations in runoff (which are assessed by the NashSutcliffe criterion) are not essential for the evaluation of future water availability, the ability of the model to reproduce monthly runoff was tested (Fig. 6). The comparison of modeled and measured monthly runoff shows a high coefficient of determination $\left(R^{2}=0.96\right)$ and proves that the model performs well on a monthly time step.

While the use of daily data enables a differentiated evaluation of the model performance, the hydrological regime and the temporal distribution of water resources become more clearly visible if monthly means are calculated (Fig. 7). The only month with a minor deviation among the mean values is August, where the model underestimates runoff by $9 \%$ compared to the observational data. The mean (maximum) annual
Table 4

Description and units of the calibrated parameters in the HBV-ETH model. The ranges that were allowed during calibration and the values that were found refer to calibration mode 2 .

\begin{tabular}{|c|c|c|c|c|}
\hline Parameter & Description & Unit & Range & Value \\
\hline RCF & Rainfall correction factor & - & $1.0,2.0$ & 1.15 \\
\hline SCF & Snowfall correction factor & - & $1.0,2.0$ & 1.25 \\
\hline PGRAD & Precipitation gradient & $\% / 100 \mathrm{~m}$ & 1,20 & 8.5 \\
\hline TGRAD & Temperature gradient & ${ }^{\circ} \mathrm{C} / 100 \mathrm{~m}$ & $-0.7,-0.5$ & -0.60 \\
\hline T0 & $\begin{array}{l}\text { Temperature divider (also } \\
\text { general temperature correction) }\end{array}$ & - & $-0.5,0.5$ & -0.1 \\
\hline CMIN & $\begin{array}{l}\text { Minimum degree day factor } \\
\text { on } 21 \text { December }\end{array}$ & $\begin{array}{l}\mathrm{mm}{ }^{\circ} \mathrm{C}-{ }^{1} \\
\text { day }\end{array}$ & 2,3 & 2.3 \\
\hline CMAX & $\begin{array}{l}\text { Maximum degree day factor } \\
\text { on } 21 \text { June }\end{array}$ & $\mathrm{mm}^{\circ}{ }^{\circ} \mathrm{C}-{ }^{1}$ & 3,6 & 3.7 \\
\hline RMULT & Multiplicative factor for ice melt & - & $1.0,2.0$ & 1.5 \\
\hline REXP & $\begin{array}{l}\text { Multiplicative factor to account } \\
\text { for aspect }\end{array}$ & - & $1.0,2.0$ & 1.25 \\
\hline CWH & Water holding capacity of snow & - & $0.01,0.1$ & 0.04 \\
\hline CRFR & Coefficient of refreezing & - & $0.1,0.5$ & 0.15 \\
\hline ETMAX & $\begin{array}{l}\text { Maximum evapotranspiration } \\
\text { on } 1 \text { August }\end{array}$ & $\mathrm{mm} /$ day & $2.0,5.0$ & 3.5 \\
\hline LP & $\begin{array}{l}\text { Limit for potential } \\
\text { evapotranspiration }\end{array}$ & $\mathrm{mm}$ & 100,200 & 120 \\
\hline FC & Field capacity & $\mathrm{mm}$ & 100,200 & 180 \\
\hline BETA & $\begin{array}{l}\text { Coefficient to calculate outflow } \\
\text { of soil moisture storage }\end{array}$ & - & $0.1,0.5$ & 0.25 \\
\hline LUZ & $\begin{array}{l}\text { Filling level of upper storage } \\
\text { above which surface runoff occurs }\end{array}$ & - & 10,100 & 40 \\
\hline CPERC & $\begin{array}{l}\text { Percolation from upper to lower } \\
\text { storage }\end{array}$ & $\mathrm{mm} / \mathrm{day}$ & $0.1,5$ & 0.5 \\
\hline $\mathrm{k}_{0}$ & Storage discharge constant & - & $0.01,0.1$ & 0.03 \\
\hline $\mathrm{k}_{1}$ & Storage discharge constant & - & $0.01,0.1$ & 0.014 \\
\hline $\mathrm{k}_{2}$ & Storage discharge constant & - & $0.001,0.01$ & 0.002 \\
\hline
\end{tabular}

share of ice melt in total runoff is $32 \%$ (43\%), not considering if this water flows through the ground water body on its way to the basin outlet or not. The highest contributions of ice melt in the Tanimas river are reached in August, with mean (maximum) shares of $68 \%$ (88\%).

\subsection{Runoff scenarios for 2050}

The monthly hydrographs of the scenarios are displayed in Fig. 8.

Numerical changes are listed in Table 5 . For the sake of a better comparability, absolute runoff values have been transformed into relative changes.

It is important to note that annual runoff remains stable, while the seasonal distribution shifts towards a water surplus in May-June and a shortage in July-September. In August and September, both scenarios a

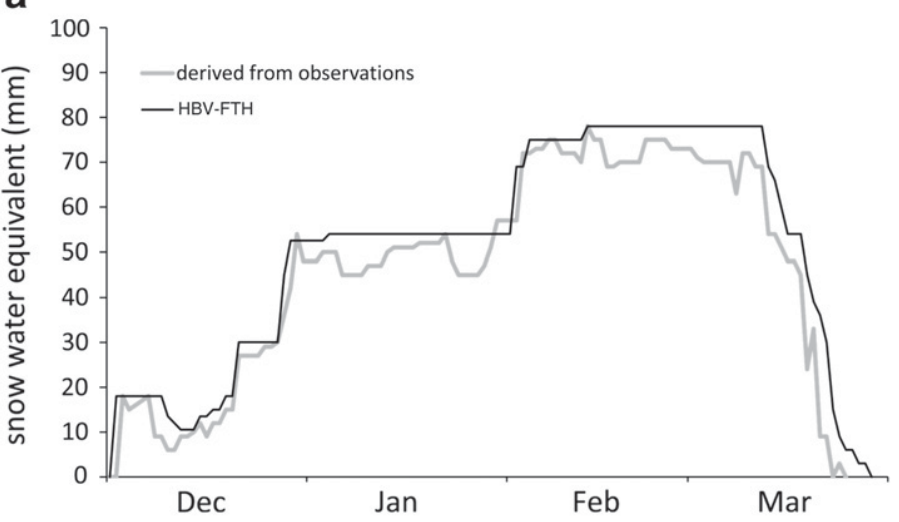

b

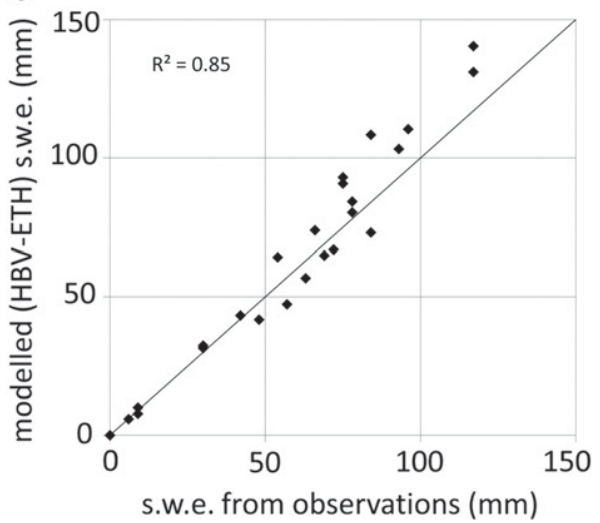

Fig. 4. Snow water equivalents modeled by HBV-ETH and derived from snow height observations at Irkht (3290 m a.s.l.). a: Daily course of snow water equivalents in an example year (1987/88), b: Monthly snow water equivalents during the calibration period (1985/86-1989/90). 


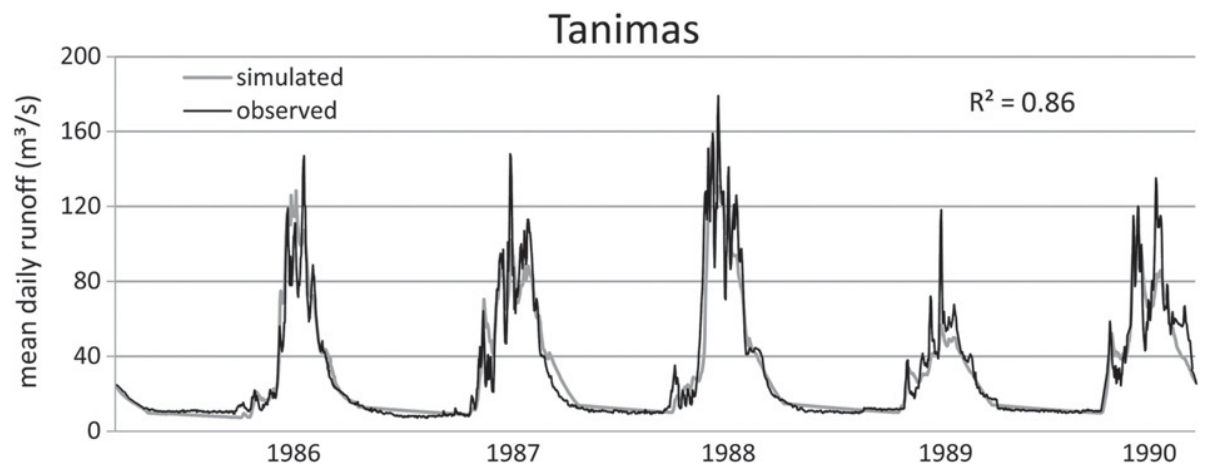

Fig. 5. Observed and simulated daily runoff at Rukhk (NSE is the model efficiency criterion after Nash and Sutcliffe, 1970).

show an identical decrease in monthly streamflow compared to the current situation.

In the "cutting lowest" mode, total summer (Jun-Sep) runoff is underestimated by $8.1 \%$ in the moderate scenario and by $5.4 \%$ in the hot scenario (Table 6).

The HBV-ETH model simulates not only runoff, but also other terms of the water balance. Their average values are listed in Table 7.

According to the presented combination of climate modeling, glacier area parameterization and runoff modeling, annual runoff will decrease by $5 \%$ until 2050 . All values in Table 7 relate to the entire catchment. Therefore, the glacier storage changes have to be regarded as basin values. Considering the respective glacierization (calibration period: $10 \%$, moderate scenario: $6.4 \%$, hot scenario: $5.5 \%$ ), the specific glacier net balances are $-1100 \mathrm{~mm} / \mathrm{a}$ for the calibration period, $-1484 \mathrm{~mm} / \mathrm{a}$ for the moderate scenario and $-1782 \mathrm{~mm} / \mathrm{a}$ for the hot scenario.

The mean shares of glacial runoff at the basin outlet, calculated as ice melt minus evapotranspiration of melted ice are $21 \%\left(+2.2{ }^{\circ} \mathrm{C}\right)$ and $24 \%\left(+3.1^{\circ} \mathrm{C}\right)$.

\section{Discussion and conclusion}

The calibration exercise with four different modes has shown that the terms of the water balance can become entirely wrong if the model is tuned by runoff only. Including glacier mass balance and snow measurements as additional criteria significantly reduces parameter uncertainty, especially if parameter values are kept within a realistic array.

The water balance in the calibration period (Table 7) is rather special for a high alpine catchment, which can be attributed to the unique combination of vast glacierization and strong aridity. Our modeled annual values for precipitation $(295 \mathrm{~mm} / \mathrm{a})$ and runoff $(215 \mathrm{~mm} / \mathrm{a})$ are

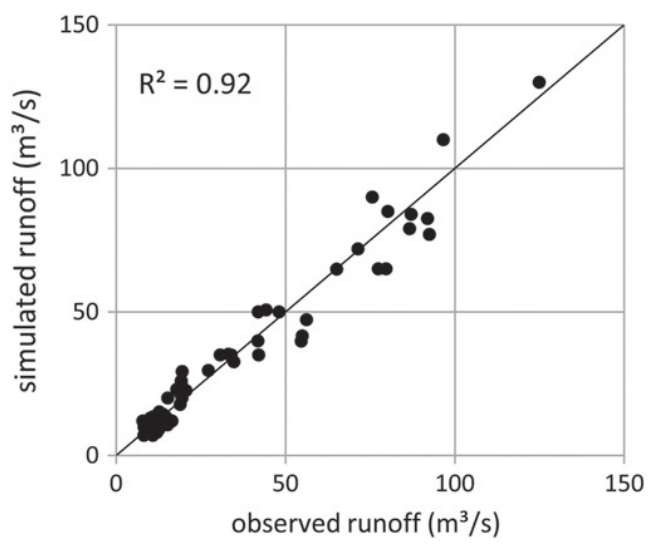

Fig. 6. Correlation between simulated and observed mean monthly runoff at Rukhk for the calibration period (1985/86-1989/90). very low, but this scale is confirmed by the latest hydrometeorological observations in Tajikistan from 1990-2005 (Finaev, 2006). Even for Central Asia, these values are exceptional. Outside the Pamir, such arid conditions can only be found in the most central parts of the Tian Shan, where mean precipitation sums of $296 \mathrm{~mm} / \mathrm{a}$ were recorded at an elevation of $3614 \mathrm{~m}$ asl (Fujita et al., 2011). Earlier applications of the HBV-ETH model (Hagg et al., 2006) have yielded basin values for precipitation of more than $500 \mathrm{~mm}$ in the Eastern Tian Shan (Glacier No. 1) and of around $1000 \mathrm{~mm}$ in the Western (Oigaing) and Northern (Tuyuksu) Tian Shan. These values match well with long-term observations (Kotlyakov, 1997; Glazyrin, 2006; Severskiy, 2006) and follow the general gradient from dry interior mountain parts to a wetter climate at the peripheral ranges (Aizen et al., 1997; Sorg et al., 2012). Modeled evapotranspiration in the Rukhk catchment $(187 \mathrm{~mm})$ is within the relative broad range of values reported from the more maritime European Alps, where estimates range from $120 \mathrm{~mm} / \mathrm{a}$ (Braun et al., 2007) to $259 \mathrm{~mm} / \mathrm{a}$ (Kuhn, 2000). Other studies from Central Asia (e.g. Kuzmichenok, 2006) confirmed evapotranspiration sums similar to those in more humid environments. This can be explained by the low water availability. While potential evaporation is surely much higher than in a moist climate, actual evaporation is strongly reduced by the low availability during the dry summers. Glacier mass balance $(-105 \mathrm{~mm} / \mathrm{a})$ is in the same order of magnitude as in the Alps, which was a requirement for model calibration. Since precipitation is strongly reduced in the Pamir, this term has a greater relative importance: in our study, the glacier storage changes are $1 / 3$ of basin precipitation or $1 / 4$ of total water input to the system (sum of precipitation and glacier wastage). In the Alps, typical corresponding values would be $1 / 5$ and $1 / 6$ (Braun et al., 2007). This comparison once more shows how much this region depends on melt water and how much glacier wastages currently contribute to water supply.

Based on climate and glacier projections for 2050, the hydrological model generates annual runoff values which are only a little below the ones in the 1980s. The slightly increased precipitation is

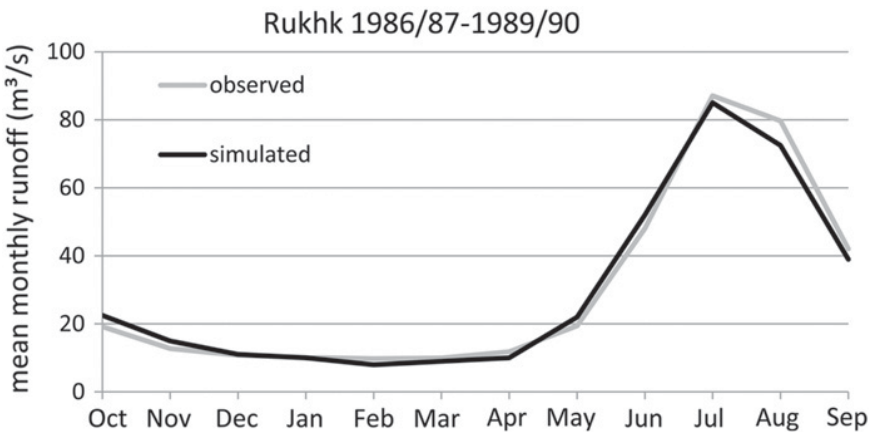

Fig. 7. Observed and simulated monthly runoff at Rukhk in the calibration period. 


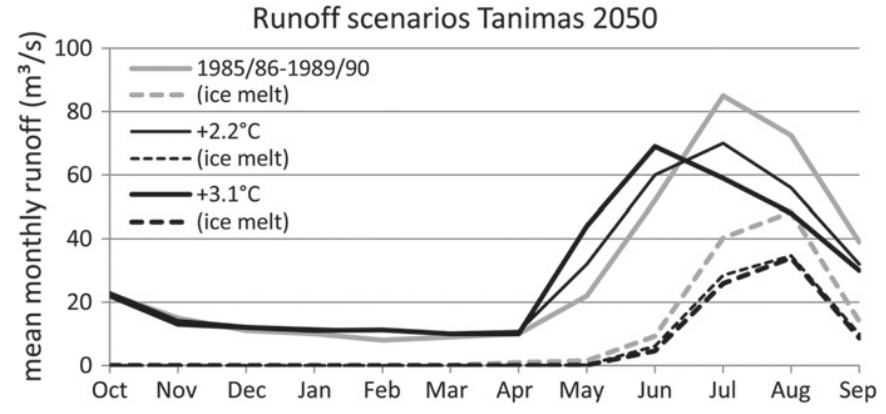

Fig. 8. Baseline and future scenarios for Tanimas river. Total runoff (solid lines) and ice melt (dashed lines) at the basin outlet (Rukhk hydrological post) are displayed.

overcompensated by a moderate increase in evapotranspiration and a small decrease in glacial runoff. The areal glacier reduction is almost compensated by enhanced melt rates in the warmer atmosphere. In other words, glaciers will melt more intensely but over a smaller area.

The runoff increase in spring and early summer is stronger in the hot scenario, it can be attributed to an earlier and intensified snowmelt. In July, the glacier area decrease in the two scenarios overcompensates enhanced melt rates due to warming, resulting in lower runoff values compared to the calibration period. The stronger decline in streamflow occurs in the hot scenario, where peak runoff is shifted from July to June, turning the glacial runoff regime into a nivo-glacial.

Konovalov (1985) has determined the fraction of glacial runoff, defined as the share of firn- and ice-melt in total runoff, by regional melt modeling for numerous catchments in Central Asia. Kudara is a hydrological post at Tanimas river some $15 \mathrm{~km}$ above Rukhk, with a glacierization of $13.8 \%$ (compared to $10 \%$ at Rukhk). Here, Konovalov (1985) determined a mean annual glacial contribution of $37 \%$, which fits very well to our result of $32 \%$. These fractions are very high compared to more humid climates. In the European Alps, similar contributions of annual glacier melt to total runoff were reported for a glacierization of 35\% (Weber et al., 2010).

Reducing glacier cover by simply cutting off the lowest areas leads to an exaggerated loss of the most melt-relevant glacier parts. An elevation-distributed deglacierization also affects higher areas and as a consequence preserves glacier areas in lower elevation bands, as is also the case in nature. The error between the two approaches is not large and it diminishes with deglacierization, because the absolute differences between the approaches also decrease with total glacier area. However, the elevation distributed deglacierization approach is a step towards more realistic runoff scenarios.

Uncertainties arise at all stages of the modeling process, beginning with the climate models (Meehl et al., 2007a). Especially in mountain regions, the confidence in the projected precipitation change remains weak. The GCMs fail in part to model precipitation accurately across varying elevations (Agaltseva et al., 2005). Differing precipitation sums and intra-annual changes would influence future runoff in two main ways: solid precipitation contributes to accumulation in winter and reduces ablation in summer, both affecting the glacier mass balance and consequently the future glacier extent. Liquid precipitation that falls on ice and rock surfaces runs off immediately and in this arid region even small absolute changes would have a large impact on runoff formation. In this context, it is important to
Table 6

Mean monthly runoff in the Rukhk catchment derived by model runs using different approaches to implement deglaciation. Elevation distributed deglaciation considers area changes in every elevation belt according to the results of the parameterization scheme (Haeberli and Hoelzle, 1995), whereas "cutting lowest" excludes glacier extent in the lowest elevation classes until the anticipated total deglaciation is reached.

\begin{tabular}{clrrrr}
\hline & & Jun & Jul & \multicolumn{1}{c}{ Aug } & \multicolumn{1}{c}{ Sep } \\
\hline Moderate scenario & Elevation distributed $\left(\mathrm{m}^{3} / \mathrm{s}\right)$ & 60.1 & 69.8 & 55.9 & 32.1 \\
$\left(+2.2^{\circ} \mathrm{C}\right)$ & Cutting lowest $\left(\mathrm{m}^{3} / \mathrm{s}\right)$ & 56.5 & 65.3 & 49.4 & 29.0 \\
& Difference $(\%)$ & -6.0 & -6.4 & -11.6 & -9.7 \\
Hot scenario & Elevation distributed $\left(\mathrm{m}^{3} / \mathrm{s}\right)$ & 68.8 & 58.9 & 48.1 & 30.1 \\
$\left(+3.1^{\circ} \mathrm{C}\right)$ & Cutting lowest $\left(\mathrm{m}^{3} / \mathrm{s}\right)$ & 65.5 & 55.3 & 45.9 & 28.1 \\
& Difference $(\%)$ & -4.8 & -6.1 & -4.6 & -6.6 \\
\hline
\end{tabular}

state that the presented results are no predictions, but have to be regarded as estimates of possible changes. More uncertainty is caused by the use of only one meteorological station and by the assumption that parameter values found in the calibration period are still valid in the future. Possible changes in the relation between air temperature and melt rates could yield substantial errors in the estimates of future glacierization and streamflow response. Not considering the effect of supraglacial debris cover overestimates both the area retreat and future melt rates. On the catchment scale, these errors partly compensate for each other and are generally small due to the very limited extent of supraglacial debris.

The mean runoff reduction in July and August of approximately $25 \%$ would raise major problems for irrigation and drinking water supply. Irrigation capacities are already limited by summer runoff and a further decrease will intensify the situation in the lowlands. Furthermore, evapotranspiration losses in the downstream regions will be significantly higher than in the headwaters treated in this study, which will further limit water availability in summer. The transnational character of the Amu-Darya requires multilateral planning of adaption strategies and impact mitigation to secure the livelihood of the population.

We trust that the applied methodology is a practical but also reliable way to estimate future water availability in regions with sparse data. The incorporation of real estimates of future glacier areas and the consideration of elevation distributed area changes in particular improved the validity of the results and the power of the approach to provide scenario estimates.

\section{Acknowledgments}

The authors thank Susan Braun-Clarke for editing the English in a very professional way. Astrid Lambrecht provided glacier shapes which are displayed in Fig. 1. Birgit Mannig, Mark Reyes and Reinhard Schiemann gave valuable advice and assistance for modeled and gridded climate data. The work was supported by the "Research Network Water in Central Asia (CAWa)", funded by the German Federal Foreign Office. Elisabeth Mayer was supported by the Deutsche Forschungsgemeinschaft (DFG, German Research Foundation) in the frame of the AKSU-TARIM project bundle (project HA 5061/2-1). ECMWF ERA-40 data used in this study have been provided by ECMWF. The valuable comments of Markus Konz, Nina Köplin and an anonymous reviewer are greatly acknowledged.

Table 5

Relative monthly runoff changes in the Rukhk catchment for the two regional climate scenarios compared to the calibration period (1985/86-1989/90).

\begin{tabular}{llllllllllllll}
\hline & Oct & Nov & Dec & Jan & Feb & Mar & Apr & May & Jun & Jul & Aug & Sep & Year \\
\hline Moderate scenario $\left(+2.2^{\circ} \mathrm{C}\right)$ & 1.02 & 0.95 & 1.12 & 1.16 & 1.37 & 1.14 & 1.07 & 1.45 & 1.15 & 0.82 & 0.77 & 0.82 & 0.96 \\
Hot scenario $\left(+3.1^{\circ} \mathrm{C}\right)$ & 0.98 & 0.87 & 1.09 & 1.10 & 1.40 & 1.11 & 1.00 & 2.00 & 1.33 & 0.69 & 0.66 & 0.77 & 0.95 \\
\hline
\end{tabular}


Table 7

Mean annual terms of the water balance in the Rukhk catchment as determined by the HBV-ETH-model $(\mathrm{Q}=$ runoff, $\mathrm{P}=$ basin precipitation, $\mathrm{ET}=$ basin evapotranspiration, $\mathrm{GMB}=$ glacier mass balance) in $\mathrm{mm} / \mathrm{a}$.

\begin{tabular}{llllr}
\hline & Q & P & ET & GMB \\
\hline Calibration period & 215 & 295 & 187 & -105 \\
Moderate scenario $\left(+2.2{ }^{\circ} \mathrm{C}\right)$ & 205 & 304 & 193 & -95 \\
Hot scenario $\left(+3.1^{\circ} \mathrm{C}\right)$ & 203 & 307 & 203 & -98 \\
\hline
\end{tabular}

\section{References}

Agaltseva, N., Spectorman, T., White, C., Tanton, T., 2005. Modelling the future climate of the Amu Darya Basin. In: Olsson, O., Bauer, M. (Eds.), Interstate Water Resource Risk Management: Towards a Sustainable Future for the Aral Basin. IWA Publishing, London, UK, pp. 9-36.

Aizen, V.B., Aizen, E.M., Melack, J.M., Dozier, J., 1997. Climatic and hydrologic changes in the Tien Shan, Central Asia. Journal of Climate 10, 1393-1404.

Akhtar, A., Ahmad, N., Booij, M.J., 2008. The impact of climate change on the water resources of Hindukush-Karakorum-Himalaya region under different glacier coverage scenarios. Journal of Hydrology 355, 148-163.

Bauder, A., Funk, M., Gudmundsson, G.H., 2003. The ice-thickness distribution of Unteraargletscher, Switzerland. Annals of Glaciology 37, 331-336.

Baumann, S., Winkler, S., 2010. Parameterization of glacier inventory data from Jotunheimen/Norway in comparison to the European Alps and the Southern Alps of New Zealand. Erdkunde 64, 155-177.

Bekchanov, M., Lamers, J.P., Martius, C., 2010. Pros and cons of adopting water-wise approaches in the lower reaches of the Amu Darya: a socio-economic view. Water 2, 200-216.

Bergström, S., 1976. Development and application of a conceptual runoff model for Scandinavian catchments. : Department of Water Resources Engineering, University of Lund, Bulletin Series A 52. Swedish Meteorological and Hydrological Institute. Norrköping, Sweden.

Braun, L.N., Hagg, W, 2009. Present and future impact of snow cover and glaciers on runoff from mountain regions - comparison between Alps and Tien Shan. In: Braun, L., Hagg, W., Severskiy, I., Young, G. (Eds.), Assessment of Snow. : Glacier and Water Resources in Asia. IHP/HWRP, Koblenz, pp. 36-43.

Braun, L.N., Renner, C.B., 1992. Applications of a conceptual runoff model in different physiographic regions of Switzerland. Hydrological Sciences Journal 73, 217-231.

Braun, L.N., Grabs, W., Rana, B., 1993. Application of a conceptual precipitation-runoff model in the Langtang-Khola Basin, Nepal Himalaya. IAHS Publ., 218, pp. 221-237. Braun, L.N., Weber, M., Schulz, M., 2000. Consequences of climate change for runoff from Alpine regions. Annals of Glaciology 31, 19-25.

Braun, L.N., Escher-Vetter, H., Siebers, M., Weber, M., 2007. Water balance of the highly glaciated Vernagt basin, Oetztal Alps. In: Psenner, R., Lackner, R. (Eds.), Alpine Space - Man \& Environment. : The Water Balance of the Alps, 3. Innsbruck University Press, Innsbruck, pp. 33-42.

Carter, T.R., Jones, R., Lu, X., Bhadwa, I S., Conde, C., Mearns, L.O., O'Neill, B.C. Rounsevell, M., Zurek, M., 2007. New assessment methods and the characterisation of future conditions. In: Parry, M.L., Canziani, O.F., Palutikof, J.P., van der Linden, P.J., Hanson, C.E. (Eds.), Climate Change 2007: Impacts, Adaptation and Vulnerability. Contribution of Working Group II to the Fourth Assessment Report of the Intergovernmental Panel on Climate Change. Cambridge University Press, Cambridge, UK, pp. 133-171.

Conrad, C., Dech, S.W., Hafeez, M., Lamers, J.P.A., Martius, C., Strunz, G., 2007. Mapping and assessing water use in a Central Asian irrigation system by utilizing MODIS remote sensing products. Irrigation and Drainage Systems 21, 197-218. http://dx.doi.org/ 10.1007/s10795-007-9029-z.

Douville, H., Royer, J.-F., Mahfouf, J.-F., 1995. A new snow parameterization for the Meteo-France climate model. Part I: validation in stand-alone experiments. Climate Dynamics 12, 21-35.

Farinotti, D., Huss, M., Bauder, A., Funk, M., Truffer, M., 2009. A method for estimating the ice volume and ice thickness distribution of alpine glaciers. Journal of Glaciology 191, $422-430$.

Finaev, A., 2006. Review of hydrometeorological observations in Tajikistan for the period of 1990-2005. In: Braun, L., Hagg, W., Severskiy, I., Young, G. (Eds.), Assessment of Snow. : Glacier and Water Resources in Asia. IHP/HWRP, Koblenz, pp. 55-64.

Froebrich, J., Kayumov, O., 2004. Water management aspects of Amu Darya. In: Nihoul, J.C.J., Zavialov, P.O., Micklin, P.P. (Eds.), Dying and Dead Seas - Climatic Versus Anthropic Causes. Kluwer Academic Publishers, Dordrecht, Netherlands, pp. 49-76.

Fujita, K., Takeuchi, N., Nikitin, S.A., Surazakov, A.B., Okamoto, S., Aizen, V.B., Kubota, J. 2011. Favorable climatic regime for maintaining the present-day geometry of the Gregoriev Glacier, Inner Tien Shan. Cryosphere 5, 539-549.

Glantz, M.H., 2005. Water, climate, and development issues in the Amu Darya Basin. Mitigation and Adaptation Strategies for Global Change 10, 23-50. http://dx.doi.org/ 10.1007/s11027-005-7829-8.

Glazyrin, G.E., 2006. Hydrometeorological monitoring system in Uzbekistan. In: Braun, L., Hagg, W., Severskiy, I., Young, G. (Eds.), Assessment of Snow. IHP/HWRP, Koblenz, pp. 65-83.

Gupta, H.V., Sorooshian, S., Yapo, P.O., 1999. Status of automatic calibration for hydrologic models: comparison with multilevel expert calibration. Journal of Hydrologic Engineering 4, 135-143.
Haeberli, W., Hoelzle, M., 1995. Application of inventory data for estimating characteristics of and regional climate-change effects on mountain glaciers: a pilot study with the European Alps. Annals of Glaciology 21, 206-212.

Hagg, W., Braun, L.N., Uvarov, V., Makarevich, K.G., 2004. Comparison of three methods for mass balance, Tien Shan. Journal of Glaciology 171, 505-510.

Hagg, W., Braun, L.N., Weber, M., Becht, M., 2006. Runoff modeling in glacierized Central Asian catchments for present-day and future climate. Nordic Hydrology 37, 93-105.

Hagg, W., Braun, L.N., Kuhn, M., Nesgaard, T.I., 2007. Modeling of hydrological response to climate change in glacierized Central Asian catchments. Journal of Hydrology $332,40-53$.

Hagg, W., Shahgedanova, M., Mayer, C., Lambrecht, A., Popvnin, V., 2010. A sensitivity study for water availability in the Northern Caucasus based on climate projections. Global and Planetary Change 73, 161-171. http://dx.doi.org/10.1016/ j.gloplacha.2010.05.005.

Hock, R., 2003. Temperature index melt modelling in mountain areas. Journal of Hydrology 282, 104-115. http://dx.doi.org/10.1016/S0022-1694(03)00257-9.

Hoelzle, M., Haeberli, W., 1995. Simulating the effects of mean annual air temperature changes on permafrost distribution and glacier size. An example from the Upper Engadin, Swiss Alps. Annals of Glaciology 2, 400-405.

Hoelzle, M., Haeberli, W., Dischl, M., Peschke, W., 2003. Secular glacier mass balances derived from cumulative glacier length changes. Global and Planetary Change 36, 295-306.

Hoelzle, M., Chinn, T.J., Stumm, D., Paul, F., Zemp, M., Haeberli, W., 2007. The application of inventory data for estimating characteristics of and regional past climate-change effects on mountain glaciers: a comparison between the European Alps and the New Zealand Alps. Global and Planetary Change 56, 69-82.

Hoelzle, M., Hagg, W., Wagner, S., 2010. Future glaciation and river flow in the Vakhsh and Panj drainage basins, Central Asia. EGU General Assembly, Vienna, Austria, 2-7 May 2010, EGU2010-6285.

Huss, M., Jouvet, G., Farinotti, D., Bauder, A., 2010. Future high-mountain hydrology: a new parameterization of glacier retreat. Hydrology and Earth System Sciences 14 , 815-829.

ICWC, 2010. http://www.icwc-aral-uz./bwoamu.htm (last access: 21 November 2010).

Jansson, P., Hock, R., Schneider, P., 2003. The concept of glacier storage: a review. Journal of Hydrology 282, 116-129.

Jòhannesson, T., Raymond, C., Waddington, E., 1989. Time-scale for adjustment of glaciers to changes in mass balance. Journal of Glaciology 121, 355-369.

Jouvet, G., Huss, M., Blatter, H., Picasso, M., Rappaz, J., 2009. Numerical simulation of Rhonegletscher from 1874 to 2100. Journal of Computational Physics 228, 6426-6439.

Juen, I., Kaser, G., Georges, C., 2007. Modelling observed and future runoff from a glacierized tropical catchment (Cordillera Blanca, Perú). Global and Planetary Change 59, 37-48.

Kaser, G., Großhauser, M., Marzeion, B., 2010. Contribution potential of glaciers to water availability in different climate regimes. Proceedings of the National Academy of Sciences of the United States of America 107, 20223-20227.

Klemeš, A., 1986. Operational testing of hydrological simulation models. Hydrological Sciences Journal 31, 13-24.

Koboltschnig, G.R., Schoener, W., Zappa, M., Kroisleitner, C., Holzmann, H., 2008. Runoff modelling of the glacierized Alpine Upper Salzach basin (Austria): multi-criteria result validation. Hydrological Processes 22, 950-3964. http://dx.doi.org/10.1002/hyp.7112.

Konovalov, V.G., 1985. Tayanie I Stok s Lednikov v Basseinah rek Srednei Azii (Melt and glacier runoff in Central Asian river basins). Gidrometeoizdat, Leningrad.

Konz, M., Uhlenbrook, S., Braun, L., Shrestha, A., Demuth, S., 2007. Implementation of a process-based catchment model in a poorly gauged, highly glacierized Himalayan headwater. Hydrology and Earth System Sciences 11, 1323-1339.

Kotlyakov, V.M. (Ed.), 1997. World Atlas of Snow and Ice Resources, vol. 2. Russian Academy of Sciences, Institute of Geography, Moscow, Russian Federation.

Kuhn, M., 1990. Energieaustausch Atmosphäre - Schnee und Eis. Schnee, Eis und Wasser der Alpen in einer wärmeren Atmosphäre. Versuchsanstalt für Wasserbau, Hydrologie, Glaziologie. ETH Zürich, Zürich, pp. 21-32.

Kuhn, M., 1993. Possible future contributions to sea level change from small glaciers. In: Warrick, R.A., Barrow, E.M., Wigley, T.M.L. (Eds.), Climate and Sea Level Change Observations, Projections and Implications. Cambridge University Press, Cambridge, UK, pp. 134-143.

Kuhn, M., 2000. Redistribution of snow and glacier mass balance from a hydrometeorological model. Journal of Hydrology 282, 95-103.

Kuzmichenok, V., 2006. Monitoring of water, snow and glacial resources of Kyrgyzstan. In: Braun, L., Hagg, W., Severskiy, I., Young, G. (Eds.), Assessment of Snow. : Glacier and Water Resources in Asia. IHP/HWRP, Koblenz, pp. 84-98.

Lambrecht, A., Mayer, C., 2009. Temporal variability of the non-steady contribution from glaciers to water discharge in western Austria. Journal of Hydrology 376, 36-353.

Lambrecht, A., Mayer, C., Surazakov, A., Aizen, V., 2010. Changes of Fedchenko Glacier, Pamir, during the last 81 years. EGU General Assembly, Vienna, Austria, 2-7 May 2010, EGU2010-1522.

Le Meur, E., Gagliardini, O., Zwinger, T., Ruokolainen, J., 2004. Glacier flow modelling: a comparison of the shallow ice approximation and the full-Stokes solution. Physique 5, 709-722.

Mannig, B., Müller, M., Starke, E., Merkenschlager, C., Mao, W., Zhi, X., Podzun, R., Jacob, D., Paeth, H., 2013. Dynamical downscaling of climate change in Central Asia. Global and Planetary Change 110, 24-37 (this issue).

March, R.S., 2000. Mass Balance, Meteorological, Ice Motion, Surface Altitude, Runoff, and Ice Thickness Data at Gulkana Glacier, Alaska, 1995 Balance Year. U.S. Geological Survey Water Resources Investigations Report.

Martius, C., Froebrich, J., Nuppenau, E.-A., 2009. Water resource management for improving environmental security and rural livelihoods in the irrigated Amu Darya 
lowlands. Hexagon Series on Human and Environmental Security and Peace 4, 749-761. http://dx.doi.org/10.1007/978-3-540-68488-6_57.

Mayr, E., Hagg, W., Mayer, C., Braun, L., 2013. Influence of annual and winter mass balance on the calibration results of a spatially distributed conceptual hydrological model. Journal of Hydrology 478, 40-49.

Meehl, G.A., Stocker, T.F., Collins, W.D., Friedlingstein, P., Gaye, A.T., Gregory, J.M., Kitoh, A., Knutti, A., Murphy, J.M., Noda, A., Raper, S.C.B., Watterson, I.G., Weaver, A.J. Zhao, Z.-C., 2007. Global climate projections. In: Solomon, S., Qin, D., Manning, M. Chen, Z Marquis, M. Averyt, K. B, Tignor, M. Miller, H.L (Eds.) Climate Change 2007: The Physical Science Basis. : Contribution of Working Group I to the Fourth Assessment Report of the Intergovernmental Panel on Climate Change. Cambridge University Press, Cambridge, UK.

Meehl, G.A., Covey, C., Delworth, T., Latif, M., McAvaney, B., Mitchell, J.F.B., Stouffer, R.J. Taylor, K.E. 2007. The WCRP CMIP3 multimodel dataset - a new era in climate change research, B. American Meteorological Society 88, 1383-1394.

Micklin, P., 2007. The Aral Sea disaster. Annual Review of Earth and Planetary Sciences 35, 47-72.

Moriasi, D.N., Arnold, J.G., van Liew, M.W., Bingner, R.L., Harmel, R.D., Veith, T.L., 2007. Model Evaluation Guidelines for Systematic Ouantification of Accuracy in Watershed Simulations, 50 885-900.

Nakicenovic, N., Alcamo, J., Davis, G., de Vries, B., Fenhann, J., Gaffin, S., Gregory, K. Grübler, A., Jung, T.Y., Kram, T., Lebre La Rovere, E., Michaelis, L., Mori, S., Morita, T., Pepper, W., Pitcher, H., Price, L., Riahi, K., Roehrl, A., Rogner, H.H., Sankovski, A., Schlesinger, M., Shukla, P., Smith, S., Swart, R., van Rooyen, S., Victor, N., Dadi, Z., 2000. IPCC Special Report on Emissions Scenarios (SRES). Cambridge University Press, Cambridge, UK.

Nash, J.E., Sutcliffe, J.V., 1970. River flow forecasting through conceptual models. Part I - a discussion of principles. Journal of Hydrology 10, 282-290.

Ohmura, A., 2001. Physical basis for the temperature-based melt index method. J. Appl. Meteorol. 40, 753-761

Paterson, W.S.B., 1994. The Physics of Glaciers, 3rd edition. Pergamon Press, Oxford.

Paul, F., 2010. Towards a global glacier inventory from satellite data. Swiss Journal of Geography 65, 103-112.

Pertziger, F., 1996. Abramov glacier data reference book: climate, runoff. Mass Balance. SANIIGMI, Tashkent, Uzbekistan.

Prudhomme, C., Wilby, R., Crooks, S., Kay, A., Reynard, N., 2010. Scenario-neutra approach to climate change impact studies: application to flood risk. Journal of Hydrology 390, 198-209. http://dx.doi.org/10.1016/j.jhydrol.2010.06.043, 2010.

Raup, B.H., Racoviteanu, A., Khalsa, S.J.S., Helm, C., Armstrong, R., Arnaud, Y., 2007. The GLIMS geospatial glacier database: a new tool for studying glacier change. Global and Planetary Change 56, 101-110. http://dx.doi.org/10.1016/j.gloplacha.2006.07.018.

Schaefli, B., Huss, M., 2010. Integrating point glacier mass balance observations into hydrologic model identification. Hydrology and Earth System Sciences 15, 1227-1241. http://dx.doi.org/10.5194/hess-15-1227-2011.

Schaefli, B., Hingray, B., Niggli, M., Musy, A., 2005. A conceptual glacio-hydrological model for high mountainous catchments. Hydrology and Earth System Sciences 9, 95-109.

Schaefli, B., Hingray, B., Musy, A., 2007. Climate change and hydropower production in the Swiss Alps: quantification of potential impacts and related modelling uncertainties. Hydrology and Earth System Sciences 11, 1191-1205.
Schär, C., Vasilina, L., Pertziger, F., Dirren, S., 2004. Seasonal runoff forecasting using precipitation from meteorological data assimilation systems. Journal of Hydrometeorology 5, 959-973.

Schiemann, R. Lüthi, D. Vidale, P.L., Schär, C., 2008. The precipitation climate of Central Asia - intercomparison of observational and numerical data sources in a remote semiarid region. International Journal of Climatology 28, 295-314. http://dx.doi.org/10.1002/joc.1532.

Severskiy, I., 2006. Current and projected changes of glaciations in Central Asia and their probable impact on water resources. In: Braun, L, Hagr W. Severskiy, I. Young, G. (Eds.), Assessment of Snow. Glacier and Water Resources in Asia. IHP/ HWRP, Koblenz, pp. 99-111.

Sorg, A., Bolch, T., Stoffel, M., Solomina, O., Beniston, M., 2012. Climate change impacts on glaciers and runoff in Tien Shan (Central Asia). Nature Climate Change 2, 725-731.

Stahl, K., Moore, R., Shea, J., Hutchinson, D., Cannon, A., 2008. Coupled modelling of glacier and streamflow response to future climate scenarios. Water Resources Research 44. http://dx.doi.org/10.1029/2007WR005956 (W02422).

Takashima, H., Yatagai, A., Kawamoto, H., Arakawa, O., Kamiguchi, K., 2009. Hydrological balance over northern Eurasia from gauge-based high-resolution daily precipitation data. In: Taniguchi, M. (Ed.), From Headwaters to the Ocean: Hydrological Change and Watershed Management. Taylor \& Francis, pp. 137-141.

Uhlenbrook, S., Seibert, J., Leibundgut, C., Rodhe, A., 1999. Prediction uncertainty of conceptual rainfall-runoff models caused by problems to identify model parameters and structure. Hydrological Sciences Journal 44, 779-798.

UNEP, 2006. Tajikistan: State of the Environment 2005. United Nations Environment Programme.

UNESCO, 2009. The United Nations World Water Development Report 3: Water in a Changing World. UNESCO, Paris (Earthscan, London).

Uppala, S.M., et al., 2005. The ERA-40 re-analysis. Quarterly Journal of the Royal Meteorological Society $131,961-3012$.

Verbunt, M., Gurtz, J., Jasper, K., Lang, H., Warmerdam, P., Zappa, M., 2003. The hydrological role of snow and glaciers in alpine river basins and their distributed modeling. Journal of Hydrology 282, 36-55.

Viviroli, D., Weingartner, R., 2004. The hydrological significance of mountains: from regional to global scale. Hydrology and Earth System Sciences 8, 1016-1029.

Weber, M., Braun, L., Mauser, W., Prasch, M., 2009. The relevance of glacier melt for the upper Danube River discharge today and in the future. Mitteilungsblatt des Hydrographischen Dienstes in Österreich 86, 1-29.

Weber, M., Braun, L., Mauser, W., Prasch, M., 2010. Contribution of rain, snow- and ice melt in the upper Danube discharge today and in the future. Geografia Fisica e Dinamica Quaternaria 33, 221-230.

WGMS, 1989. In: Haeberli, W., Bösch, H., Scherler, K., Østrem, G., Wallen, C.C. (Eds.) World Glacier Inventory - Status 1989. IAHS/(ICSI)/UNEP/UNESCO, Nairobi.

Zheltyhina, N., 2005. GLIMS Glacier Database. National Snow and Ice Data Center/ World Data Center for Glaciology. Digital Media, Boulder, CO.

Zingg, T., 1951. Relations between temperature and meltwater. IUGG/IAHS Publ., 32, pp. 266-269. 